\title{
Pengaruh Penambahan Asam Amino Lisin pada Pakan Komersil terhadap Efisiensi Pemanfaatan Pakan, Pertumbuhan, dan Kelulushidupan Udang Vaname (Litopenaeus vannamei)
}

\author{
Diana Rachmawati*, Sarjito, Panji Yusroni Anwar, Seto Windarto \\ Departemen Akuakultur, Fakultas Perikanan dan Ilmu Kelautan, Universitas Diponegoro \\ JI. Prof. Soedarto SH, Tembalang, Semarang 50275 \\ Email: dianarachmawati1964@gmail.com
}

\begin{abstract}
The Effect of Lysine Addition in Commercial Feed on Feed Utilization Efficiency, Growth, and Survival Rate of Vannamei Shrimp (Litopenaeus vannamei)
\end{abstract}

Reducing feed cost in the vaname (Litopenaeus vannamei) cultivation can be achieved by increasing quality of commercial feed. To increase the feed quality is by adding lysine amino acid, because lysine is one of the amino acids that can boost fish growth, in turn it can shorten the cultivation cycle. The objectives of the study were to analyze effects and optimum dosages of lysine addition in the feed on feed efficiency utilization, growth and survival rate of vaname shrimp (L. vannamei). The study used shrimp juveniles with the average size of $3 \pm 0,09 \mathrm{~g} / \mathrm{shrimp}$. Test feed in the study was a commercial feed in the form of pellets that was enriched with lysine (L-lysine HCl). The amount of lysine was appropriated to the treatment dosages, namelys $0 \% / \mathrm{kg}$ feed (A); 0,75 $\% / \mathrm{kg}$ feed (B); $1,5 \% / \mathrm{kg}$ feed (C); $2,25 \% / \mathrm{kg}$ feed (D) and $3 \% / \mathrm{kg}$ feed (E). Feeding the shrimp was based on fixed feeding rate as much as $10 \%$ of biomass weight per day and given 4 (four) times a day. The results whow that the addition of lysine in the feed significantly $(P<0,01)$ affected on the $S G R, E P P, F C R$, and PER; otherwise, it did not significantly affect on the survival rate of vaname shrimp. Meanwhile, the optimum dosages of lysine amino acids added into the feed were 2,33\%, 2,39\%, 2,37\%, and 2,09\% for SGR, EPP, FCR, and PER respectively. Those dosages resulted in the maxium values of 4,72\%/day, 81,35\%, 1,23, and 2,57 for SGR, EPP, FCR, and PER respectively.

Keywords: Litopenaeus vannamei; lysine; growth; survival rate

\begin{abstract}
Abstrak
Penurunan biaya operasional pakan dalam siklus kegiatan budidaya udang vaname (Litopenaeus vannamei) dapat dilakukan dengan meningkatkan kualitas pakan komersial. Penambahan asam amino lisin pada pakan komersial dilakukan untuk meningkatkan kualitas pakan, dikarena lisin merupakan salah satu asam amino dapat mempercepat pertumbuhan sehingga memperpendek masa produksi kultivan yang dibudidayakan. Tujuan penelitian ini untuk mengkaji pengaruh dan dosis optimum penambahan lisin pada pakan komersil terhadap efisiensi pemanfaatan pakan, pertumbuhan, dan kelulushidupan udang vaname (L. vannamei). Penelitian ini menggunakan juvenile udang vaname berukuran 3 $30,09 \mathrm{~g} / \mathrm{ekor}$. Pakan uji dalam penelitian ini adalah pakan komersil berbentuk pellet yang ditambahkan lisin (L-lysine $\mathrm{HCl}$ ) sesuai dosis tiap perlakuan yaitu $0 \% / \mathrm{kg}$ pakan (A); $0,75 \% / \mathrm{kg}$ pakan (B); $1,5 \% / \mathrm{kg}$ pakan $(\mathrm{C}) ; 2,25 \% / \mathrm{kg}$ pakan (D) dan $3 \% / \mathrm{kg}$ pakan (E). Pakan uji diberikan dengan metode fix feeding rate sebanyak 10\%/bobot biomassa/hari dan frekuensi pakan yang diberikan sebanyak 4 kali sehari. Hasil penelitian menunjukkan bahwa penambahan lisin pada pakan komersial berpengaruh sangat nyata $(P<0,01)$ terhadap SGR, EPP, FCR, dan PER akan tetapi tidak berpengaruh nyata terhadap kelulushidupan udang vaneme. Dosis optimal asam amino lisin dalam pakan komersial udang vaname untuk SGR sebesar 2,33\%, EPP sebesar 2,39\%, FCR sebesar 2,37\% dan PER sebesar 2,09\% menghasilkan SGR
\end{abstract}


maksimal sebesar 4,72\%/hari, EPP maksimal sebesar $81,35 \%$, FCR maksimal sebesar 1,23, dan PER maksimal sebesar 2,57.

Kata Kunci : Litopenaeus vannamei, lisin, pertumbuhan, kelulushidupan

\section{PENDAHULUAN}

\begin{abstract}
Udang vaname (Lithopenaeus. vannamei) adalah salah satu udang ekonomis penting yang memiliki beberapa kelebihan diantaranya adalah toleransi kondisi air, dapat tumbuh dengan cepat, dan daging yang tebal (Xia dan Wu, 2018). Dalam usaha budidaya udang, salah satu faktor penting adalah ketersediaan pakan. Namun demikian, dalam biaya operasional produksi budidaya ikan pakan menyerap biaya yang paling besar (60-70\%) dari total biaya operasional (Rachmawati et al., 2019). Salah satu cara untuk menurukan biaya operasional pakan yaitu dengan meningkatkan kualitas pakan yang tersedia. Penambahan asam amino lisin dapat dilakukan untuk meningkatkan kualitas pakan karena lisin merupakan salah satu feed additive pakan yang dapat mempercepat pertumbuhan sehingga memperpendek masa produksi kultivan yang dibudidayakan (Pramana et al., 2017). Selain itu penambahan lisin diperlukan karena sumber protein nabati penyusun pakan kekurangan asam amino lisin (Pavalesam et al., 2008). Lebih lanjut Ahmed dan Khan, (2004) menyatakan suplementasi asam amino merupakan strategi dalam pemenuhan keseimbangan asam amino pada pakan dan meningkatkan kualitas protein.
\end{abstract}

Selain itu, penambahan lysin dalam pakan dapat mengurangi kadar lemak tubuh ikan (Nguyen et al., 2013), dan meningkatkan retensi protein (Cao et al., 2012) serta berperan pada metabolism untuk pertumbuhan otot (Khan dan Abidi, 2011). Asam amino lisin berperan dalam pembentukan karnitin. Karnitin diperlukan dalam proses metabolisme lemak untuk membentuk atau menghasilkan energi, dimana karnitin berperan dalam transportasi asam lemak rantai panjang ke dalam mitokondria (Biswas et al., 2006). Penambahan $1 \%$ lisin dari jumlah pakan dapat meningkatkan efisiensi pemanfaatan protein oleh udang windu (Penaeus monodon) yang diikuti peningkatan laju pertumbuhan (Biswas et al., 2006). Penelitian
Pramana et al., (2017) menyatakan penambahan lisin pada pakan komersil untuk jenis udang seperti udang galah (Macrobrachium rosenbergii) dibawah $2 \%$ belum meningkatkan laju pertumbuhan dan efisiensi pakan. Menurut Khalida et al., (2017) kebutuhan lisin ikan bawal (Colossoma Macropomum) sebesar 1,2\%. Menurut Giri et al., (2009) kandungan lisin optimum dalam pakan untuk pertumbuhan benih kerapu sunu (Plectropomus leopardus) adalah $2,84 \%$. Berdasarkan pada latar belakang diatas maka perlu dilakukan penelitian penambahan lisin pada pakan komersial terhadap retensi protein, pertumbuhan, sistem imun dan kelulushidupan udang vaname (L. vannamei). Penelitian ini dilakukan dengan tujuan mengetahui pengaruh dan dosis optimum penambahan asam amino lisin pada pakan komersil terhadap efisiensi pemanfaatan pakan, pertumbuhan, dan kelulushidupan udang vaname (L. vannamei).

\section{MATERI DAN METODE}

Penelitian ini dilaksanakan di area pertambakkan di Dusun Bungin, Kelurahan Danasari, Kecamatan Pemalang, Kabupaten Pemalang dari bulan Juli s/d September 2019. Hewan uji yang digunakan dalam penelitian ini adalah juvenile udang vaname yang berukuran $3 \pm 0,09$ gr/ekor sejumlah 450 ekor (30 ekor pada setiap ulangan) untuk 15 ulangan yang berasal dari tempat penelitian. Hewan uji dipilih berdasarkan keseragaman ukuran, kelengkapan organ tubuh, kesehatan secara fisik dan tidak ada potensi penyakit (Rachmawati et al., 2019). Selanjutnya dilakukan adaptasi hewan uji terhadap pakan dan lingkungan selama seminggu kemudian hewan uji dipuasakan selama 1 hari sebelum dilakukan penelitian yang bertujuan untuk membuang sisa metabolisme dari pakan yang telah diberikan sebelumnya.

Pakan uji dalam penelitian ini adalah pakan komersil berbentuk pellet yang ditambahkan asam amino lisin (L-lysine $\mathrm{HCl}$ ) sesuai dosis tiap perlakuan yaitu $0 \% / \mathrm{kg}$ pakan 
(A); $0,75 \% / \mathrm{kg}$ pakan (B); $1,5 \% / \mathrm{kg}$ pakan (C); $2,25 \% / \mathrm{kg}$ pakan (D) dan $3 \% / \mathrm{kg}$ pakan (E). Dosis asam amino lisin dalam penelitian ini memodifikasi hasil penelitian Pramana et al. (2017) yang menyatakan dosis asam amino lisin $2 \% / \mathrm{kg}$ pakan meningkatkan pertumbuhan udang galah. Asam amino lisin yang digunakan adalah merk L-lysine $\mathrm{HCl}$ yang berbentuk bubuk berwarna coklat diproduksi oleh PT. Cheiljedang Indonesia. Metode pencampuran lisin dalam pakan dilakukan dengan cara menghaluskan pakan buatan terlebih dahulu. Kemudian melarutkan lisin dengan air aquades $100 \mathrm{ml}$ tiap dosis perlakuan, setelah homogen maka dicampurkan pada pakan buatan yang sudah dihaluskan. Pakan yang telah dicampur dengan lisin ditambahkan $1 \%$ CMC sebagai binder, selanjutnya dicetak kembali dengan mesin pencetak pellet dan dikeringkan dengan oven pada suhu $40^{\circ} \mathrm{C}$ hingga kering. Pakan uji diberikan sebanyak 3 kali dalam sehari. Hasil Analisis Proksimat pakan uji setelah ditambahkan lisin dapat dilihat pada Tabel 1. Selama penelitian pakan diberikan dengan metode fix feeding rate sebanyak $10 \% /$ bobot biomassa/hari dan frekuensi pakan yang diberikan sebanyak 4 kali sehari, pada pukul 07.00, 13.00,17.00, dan 20.00 WIB.

Wadah yang digunakan dalam penelitian ini adalah happa yang dibuat dari waring yang berukuran $1 \times 1 \times 1$ yang berjumlah 15 buah. Penempatan hapa pada setiap perlakuan dan pengulangan diundi secara acak. Hapa ditempatkan pada area tambak budidaya udang vaname. Penelitian ini dilakukan pada tambak trandisional dengan dasar tanah. Media pemeliharaan dalam penelitian ini menggunakan air payau salinitas yang optimal untuk budidaya udang berkisar antara 15 - 25 ppt (SNI, 2014). Parameter kualitas air selama penelitian untuk $\mathrm{pH}$ berkisar 7,6-8,4, suhu 27-30 ० $\mathrm{C}$, salinitas 15-25 ppt, DO 4-6 mg/l, alkalinitas 120-150 ppm, dan total ammonia 0,1-0,3 ppm (SNI, 2014). Perhitungan laju pertumbuhan spesifik menurut Jin et al. (2018). Efisiensi pemanfaatan pakan dihitung menggunakan rumus Tacon (1987). Perhitungan rasio konversi pakan menggunakan rumus Jin et al. (2018).Perhitungan rasio efisiensi protein menggunakan rumus Tacon (1987). Perhitungan kelulushidupan menggunakan rumus Wang et al. (2018).

Data penelitian yang diperoleh terlebih dahulu dilakukan uji normalitas, uji homogenitas dan uji, selanjutnya dilakukan analisis ragam (ANOVA). Apabila hasil ANOVA berpengaruh nyata $(P<0,05)$ atau berpengaruh sangat nyata $(P<0,01)$, maka dilanjutkan uji wilayah ganda duncan. Dosis asam amino lisin optimal pada pakan dilakukan analisis polinomial ortogonal dengan software Maple 2016 (Stell et al., 1997).

\section{HASIL DAN PEMBAHASAN}

Data laju pertumbuhan spesifik (RGR), efisiensi pemanfaatan pakan (EPP), rasio konersi pakan (FCR), protein efisiensi rasio (PER), kelulushidupan (SR) udang vaname selama penelitian disajikan pada Tabel 2.

Tabel 1. Komposisi dan Hasil Analisis Proksimat Pakan Uji (\%)

\begin{tabular}{cccccc}
\hline \multirow{2}{*}{ Komposisi pakan } & \multicolumn{7}{c}{ Perlakuan } \\
\cline { 2 - 6 } & A & B & C & D & E \\
\hline Pakan komersil & 100 & 98,25 & 97,50 & 96,75 & 96,00 \\
Lisin & 0 & 0,75 & 1,50 & 2,25 & 3,00 \\
CMC & 0 & 1,00 & 1,00 & 1,00 & 1,00 \\
\hline Kadar air* & 4,89 & 5,97 & 5,88 & 5,97 & 6,00 \\
Kadar abu* $_{\text {Protein* }}$ & 8,00 & 7,96 & 8,46 & 8,37 & 10,00 \\
Lemak $^{*}$ & 29,89 & 30,86 & 31,17 & 31,64 & 31,92 \\
Serat $^{*}$ & 8,90 & 14,34 & 8,86 & 11,30 & 7,40 \\
& 0,12 & 0,27 & 0,31 & 0,05 & 0,38 \\
\hline
\end{tabular}

* Hasil analisa proksimat Balai Penelitian dan Pengembangan Pertanian Laboratorium Penguji Balai Pengkajian Teknologi Pertanian, Ungaran, Jawa Tengah. 
Tabel 2. Nilai rata-rata laju pertumbuhan spesifik (SGR), efisiensi pemanfaatan pakan (EPP), rasio konersi pakan (FCR), protein efisiensi rasio (PER), dan kelulushidupan (SR) udang vaname selama penelitian

\begin{tabular}{cccccc}
\hline Perlakuan & \multicolumn{5}{c}{ Parameter } \\
\cline { 2 - 6 } & SGR (\%/hari) & EPP (\%) & FCR & PER & SR (\%) \\
\hline A & $4,17 \pm 0,12^{\mathrm{e}}$ & $71,22 \pm 0,47 \mathrm{e}$ & $1,40 \pm 0,01 \mathrm{e}$ & $2,37 \pm 0,02^{\mathrm{e}}$ & $84,44 \pm 1,92^{\mathrm{a}}$ \\
B & $4,42 \pm 0,05^{\mathrm{a}}$ & $75,58 \pm 1,57 \mathrm{~d}$ & $1,32 \pm 0,03^{\mathrm{d}}$ & $2,45 \pm 0,05^{\mathrm{c}}$ & $86,67 \pm 3,33^{\mathrm{a}}$ \\
C & $4,59 \pm 0,03^{\mathrm{bc}}$ & $78,41 \pm 0,54 \mathrm{bc}$ & $1,28 \pm 0,01^{\mathrm{bc}}$ & $2,52 \pm 0,02^{\mathrm{b}}$ & $87,78 \pm 1,92^{\mathrm{a}}$ \\
D & $4,84 \pm 0,03^{\mathrm{a}}$ & $83,99 \pm 1,43^{\mathrm{a}}$ & $1,19 \pm 0,02^{\mathrm{a}}$ & $2,65 \pm 0,05^{\mathrm{a}}$ & $88,89 \pm 1,92^{\mathrm{a}}$ \\
E & $4,63 \pm 0,01^{\mathrm{b}}$ & $79,55 \pm 0,44^{\mathrm{b}}$ & $1,26 \pm 0,01^{\mathrm{b}}$ & $2,49 \pm 0,01^{\mathrm{bc}}$ & $86,67 \pm 3,33^{\mathrm{a}}$ \\
\hline
\end{tabular}

Keterangan: Nilai rerata dengan huruf superscript yang berbeda menunjukkan adanya perbedaan yang nyata $(\mathrm{P}<0,05)$

Hasil uji Polinomial Orthogonal hubungan antara penambahan asam amino lisin dalam pakan komersial dengan SGR memiliki pola kuadratik $Y=-0,1072 x^{2}+0,5004 x$ $+4,1406, R^{2}=0,9043$ (Gambar 1), dari persamaan tersebut diperoleh dosis optimal asam amino lisin pada SGR sebesar 2,33\% mampu menghasilkan SGR maksimal sebesar 4,72\%/hari. Hubungan antara penambahan asam amino lisin dalam pakan komersial dengan EPP berpola kuadratik $Y=-1,8862 x^{2}+$ $9,0001 x+70,615, R^{2}=0,8411$ (Gambar 2), dari persamaan tersebut diperoleh dosis optimal asam amino pada EPP sebesar 2,39\% yang mampu menghasilkan EPP maksimal sebesar $81,35 \%$. Hubungan antara penambahan asam amino lisin dalam pakan komersial dengan FCR berpola kuadratik $Y=0,0327 x^{2}$ $0,1549 x+1,4123, R^{2}=0,8753$ (Gambar 3) dari persamaan tersebut diperoleh dosis optimal asam amino pada FCR sebesar 2,37\% yang mampu menghasilkan FCR maksimal sebesar 1,23 . Hubungan antara penambahan asam amino pada pakan komersial dengan PER berpola kuadratik $Y=-0,0505 x^{2}+0,2111 x+$ 2,3514, $R^{2}=0,6762$ (Gambar 4) dari persamaan tersebut diperoleh dosis optimal asam amino pada PER sebesar 2,09\% yang mampu menghasilkan PER maksimal sebesar $2,57 \%$.

Hasil analisis ragam menunjukkan bahwa penambahan asam amino lisin pada pakan komersial memberikan pengaruh sangat nyata $(P<0,01)$ terhadap SGR udang vaname. Berpengaruhnya penambahan asam amino lisin terhadap laju pertumbuhan diduga karena asam amino lisin dapat berfungsi sebagai penyeimbang dalam menjaga tekanan osmotik dan asam basa tubuh sehingga tidak banyak energi yang digunakan untuk menyesuaikan tekanan osmotik udang. Muhktar et al. (2017) menyatakan lisin berperan penting dalam menjaga tekanan osmotik dan keseimbangan asam-basa dalam cairan tubuh. Selain itu, ikan atau udang yang diberi pakan yang kekurangan asam amino esensial menunjukkan penurunan pertumbuhan dan tingkat kematian yang lebih tinggi. Disamping itu, diduga karena salah satu fungsi asam amino lisin dalam pembetukan kartinin. Kartinin berfungsi untuk metabolisme lemak dalam pembentuk atau penghasil energi (Xie et al., 2012). Nilai SGR udang vaname tertinggi selama penelitian didapatkan dosis asam amino lisin sebesar $2,25 \% / \mathrm{kg}$ pakan (D) sebesar 4,84\%/hari, diikuti dosis $3 \% / \mathrm{kg}$ pakan (E) sebesar $4,63 \pm \%$ /hari, dosis $1,5 \% / \mathrm{kg}$ pakan (C) sebesar $4,59 \%$ /hari, dosis $0,75 \% / \mathrm{kg}$ pakan (B) sebesar $4,42 \%$ /hari dan dosis $0 \% / \mathrm{kg}$ pakan (A) sebesar 4,17 $\%$ /hari. Hasil tersebut menunjukan bahwa dosis terbaik untuk penambahan lisin pada udang vaname yaitu perlakuan $D(2,25 \% / \mathrm{kg}$ pakan). Nilai SGR juga dipengaruhi oleh hasil EPP dan PER sehingga pakan dan kandungan protein dalam pakan dapat dimanfaatkan secara optimal oleh udang. Faktor lain yang mempengaruhi tingginya nilai SGR adalah rendahnya nilai FCR sehingga dari total pakan yang diberikan dapat dikonversikan menjadi bobot oleh udang. Hasil penelitian serupa dilaporkan oleh Palavesam et al. (2008) menyatakan suplementasi asam amino lisin 0,5\% pada pakan berprotein $35 \%$ dapat meningkatkan kinerja pertumbuhan ikan Etroplus suratensis. Giri et al. (2009) menyatakan kandungan lisin optimum dalam pakan untuk pertumbuhan benih kerapu sunu (Plectropomus leopardus) sebesar 2,84\%. Ebeneezar et al. (2019 
mrnyatakan juvenile Silver pompano (Trachinotus blochii) membutuhkan lisin sebesar $5.71-5.83 \%$ protein pakan.

Nilai EPP tertinggi didapatkan pada perlakuan dosis asam amino lisin sebesar $2,27 \%$ (D) sebesar $83,99 \%$ dan nilai terendah pada perlakuan dosis $0 \%$ (A) sebesar $71,22 \%$. Hasil tersebut menunjukan bahwa dosis terbaik penambahan asam amino lisin pada pakan terhadap EPP udang vaname sebesar 2,25\%/kg pakan, hasil tersebut juga diikuti dengan hasil lain seperti SGR, PER, FCR, dan retensi protein juga terbaik pada perlakuan $D$
$(2,25 \% / \mathrm{kg}$ pakan). Nilai EPP yang tinggi didukung juga dengan rendahnya nilai FCR, semakin rendah nilai FCR akan menghasilkan nilai EPP yang tinggi. Udang vaname yang diberi pakan mengandung asam amino lisin memiliki nilai EPP lebih tinggi dibandingkan tanpa adanya penambahan asam amino lisin, hal ini diduga asam amino lisin dapat meningkatkan kecernaan pakan. Alam et al. (2012) menyatakan ketersediaan asam amino yang tidak seimbang dan ketersediaan asam amino yang lebih rendah dalam pakan dapat memengaruhi pencernaan, penyerapan, dan metabolisme

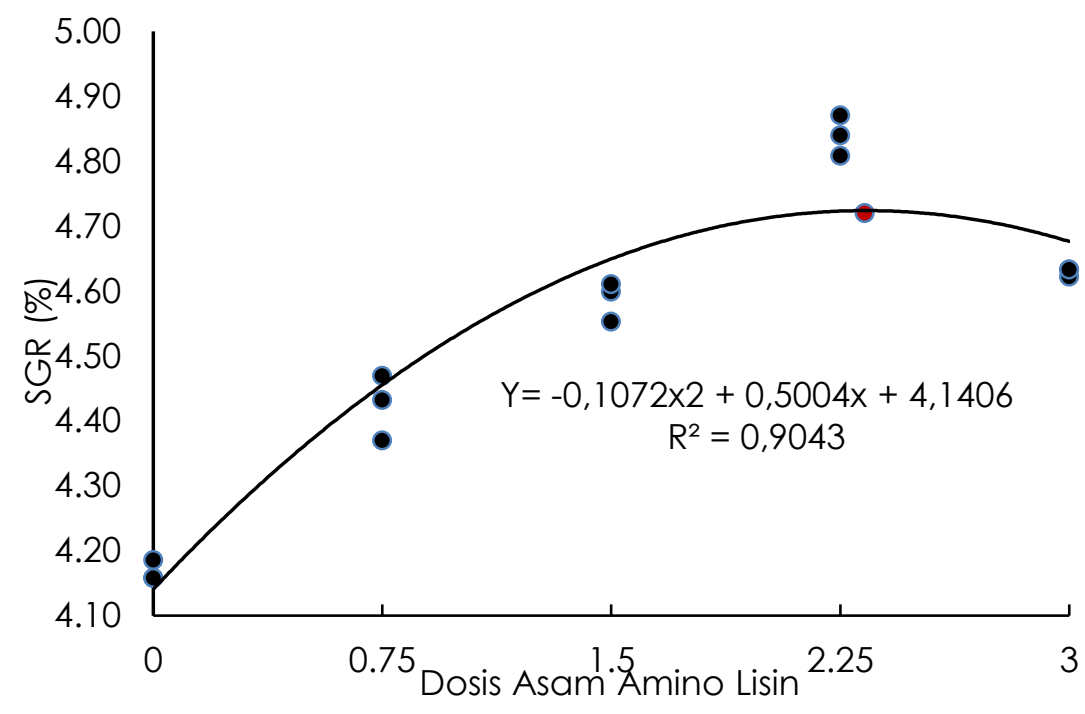

Gambar 1. Hubungan antara penambahan asam amino lisin dalam pakan dengan SGR udang vaname

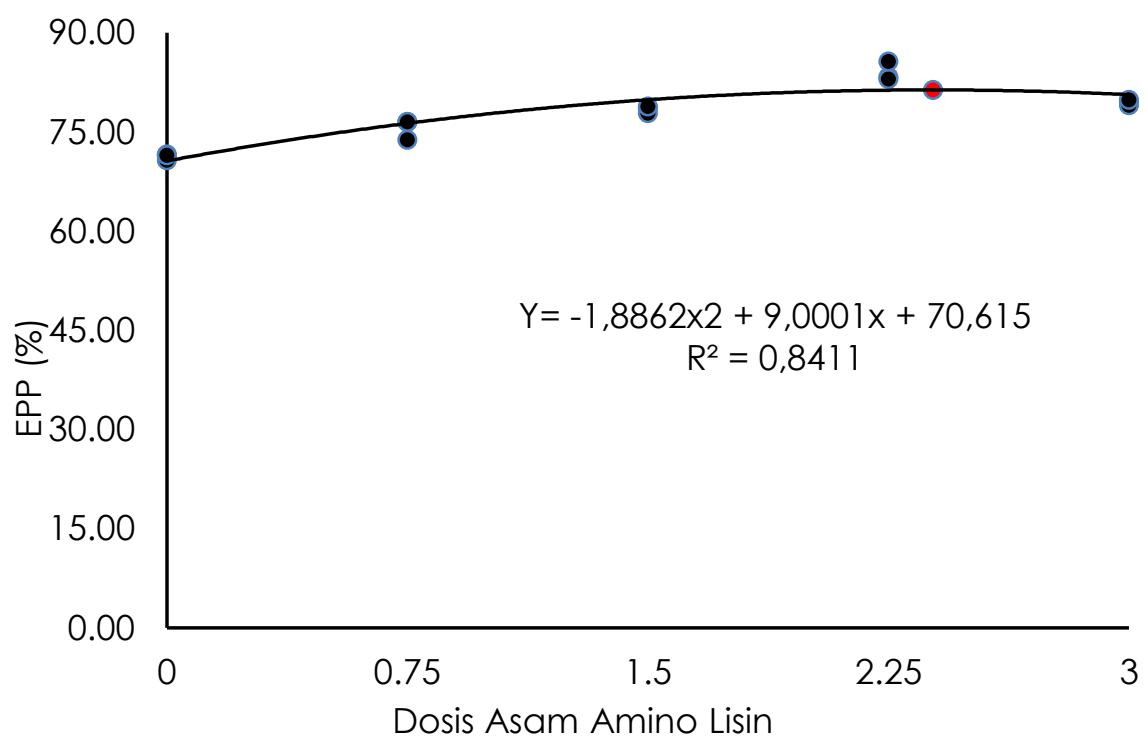

Gambar 2. Hubungan antara penambahan asam amino lisin dalam pakan dengan EPP udang vaname 
zat gizi. Penambahan lisin meningkatkan pemanfaatan pakan dan kinerja pertumbuhan ke tingkat yang baik. Palavesam et al. (2008), menyatakan lisin adalah salah satu di antara sepuluh asam amino yang sangat diperlukan yang dibutuhkan dalam protein pakan. Hal ini juga dilaporkan dalam penelitian Deng et al (2010), bahwa di antara 10 asam amino yang sangat diperlukan, Lisin sering dijadikan yang pertama sebagai pembatas asam amino dalam bahan yang digunakan dalam pakan ikan. Xie et al., (2012) menyatakan bahwa nilai EPP dan PER meningkat dengan meningkatnya kadar lisin pada pakan dan kemudian akan dipertahankan pada tingkat yang konstan.

Hasil penelitian menunjukkan nilai FCR terendah pada perlakuan dosis asam amino $2,25 \%$ (D) senilai 1,19, hasil tersebut menunjukan bahwa dosis terbaik penambahan lisin pada pakan udang vaname untuk FCR pada perlakuan D

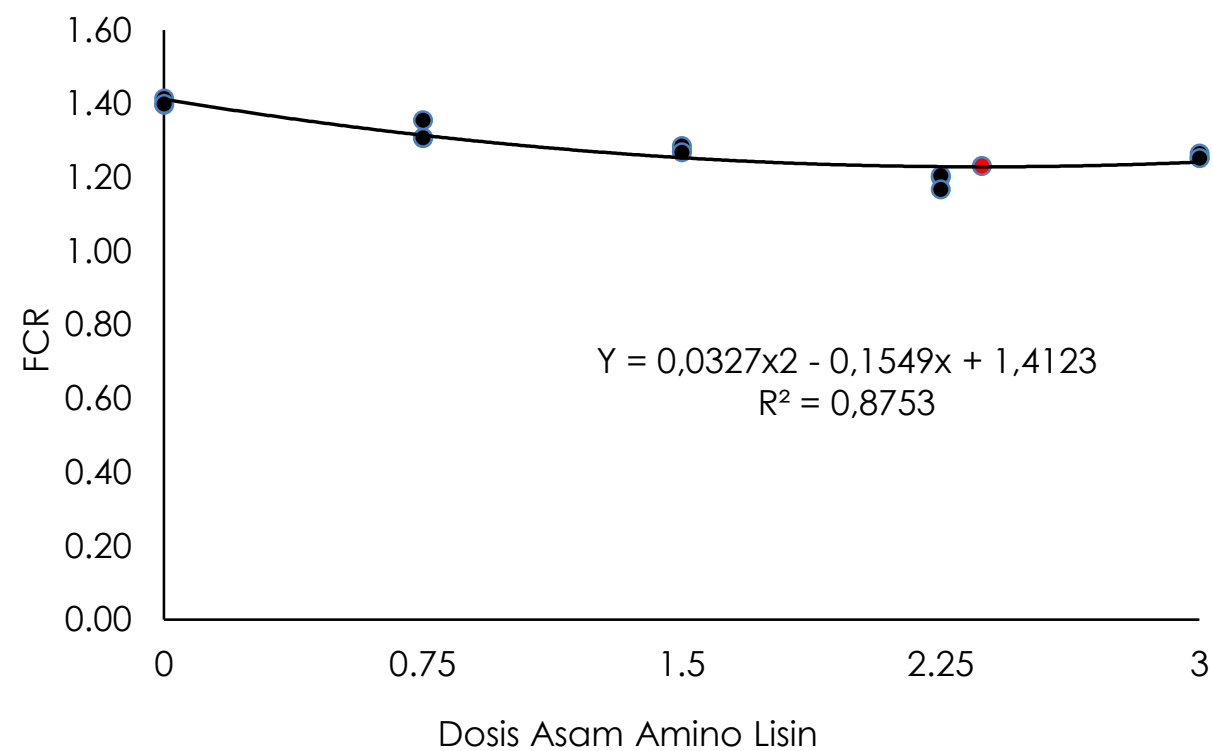

Gambar 3. Hubungan antara penambahan asam amino lisin dalam pakan dengan FCR udang vaname

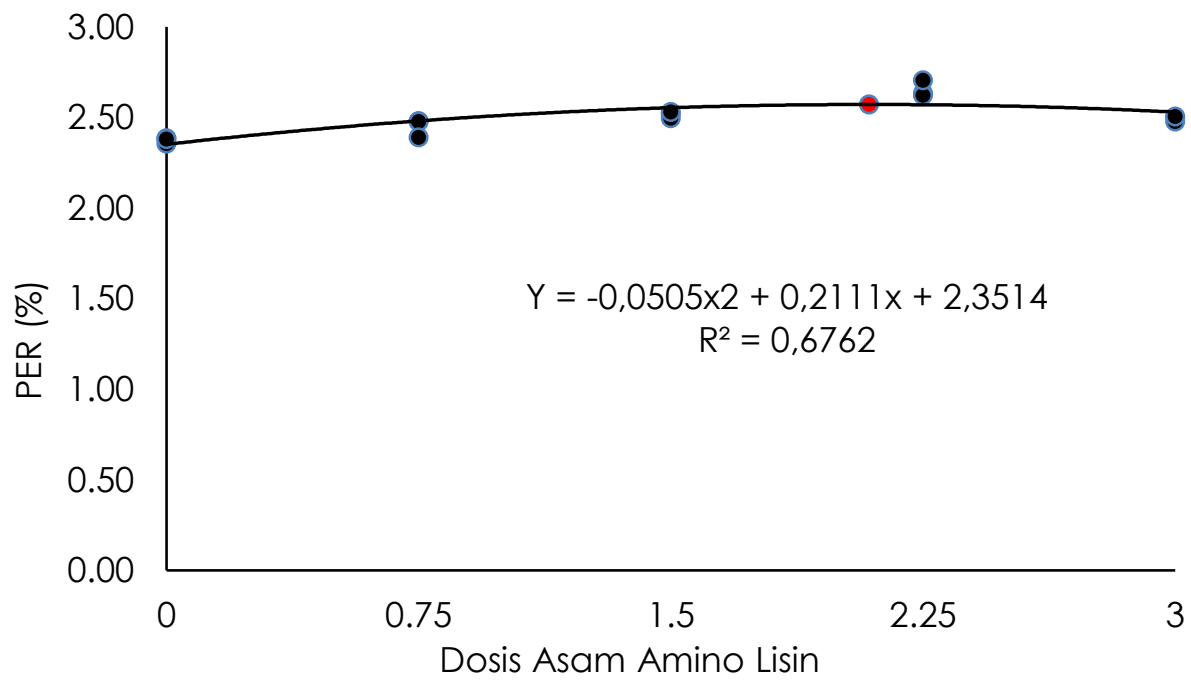

Gambar 4. Hubungan antara penambahan asam amino lisin dalam pakan dengan PER udang vaname 
$(2,25 \% / \mathrm{kg}$ pakan). Nilai FCR memiliki keterkaitan dengan nilai EPP, semakin tinggi EPP maka akan semakin rendah FCR. Rachmawati et al.(2019) menyatakan nilai FCR yang semakin kecil menunjukkan pakan yang dikonsumsi oleh ikan lebih efisien digunakan untuk pertumbuhan, sebaliknya nilai FCR yang semakin besar menunjukkan pakan yang dikonsumsi kurang efisien. Faktor yang mempengaruhi nilai FCR udang selama penelitian adalah semakin tingginya juga nilai EPP dan PER. Nilai EPP dan PER yang tinggi dapat diartikan dengan tingginya kemampuan udang untuk memanfaatkan pakan dan kandungan protein dalam pakan sehingga mampu menghasilkan nilai FCR yang rendah. Hasil FCR tersebut dikategorikan baik karena nilai FCR yang baik untuk udang berkisar 1,27 hingga 1,71. Xu et al. (2018) menyatakan nilai rasio konversi pakan yang baik pada udang vaname berada di kisaran 1,27 hingga 1,71. Semakin kecil nilai konversi pakan yang dihasilkan menunjukkan penggunaan pakan tersebut semakin efisien. Penambahan asam amino lisin pada pakan komersil dapat meningkatkan rasio efisiensi protein (PER) dan rasio konversi pakan (FCR). Hal ini dilaporkan pada penelitian Salama et al. (2016), bahwa peningkatan kadar lisin dalam pakan dapat meningkatkan rasio efisiensi protein (PER) dan rasio konversi pakan (FCR). Tingkat lisin yang lebih tinggi dari persyaratan yang disarankan tidak meningkatkan pemanfaatan pakan sedangkan kekurangan asam amino yang sangat diperlukan dapat menyebabkan pertumbuhan berkurang dan konversi pakan yang buruk. Oleh karena itu, memenuhi persyaratan asam amino sangat diperlukan dari suatu spesies adalah yang paling penting dalam menyiapkan pakan yang seimbang.

Hasil analisis ragam menunjukkan bahwa penambahan asam amino lisin pada pakan komersial berpengaruh sangat nyata $(P<0,01)$ terhadap PER udang vaname. Hasil yang didapatkan untuk nilai PER tertinggi pada perlakuan $D(2,25 \%)$ senilai 2,65 diikuti perlakuan $C(1,5 \%)$ sebesar 2,53 , perlakuan $E$ (3\%) sebesar 2,49, perlakuan B $(0,75 \%)$ sebesar 2,45 dan perlakuan A (0\%) sebesar 2,37. Berdasarkan hasil tersebut menunjukan bahwa dosis terbaik penambahan lisin pada pakan untuk PER udang vaname adalah dosis $2,25 \%$ (D). Nilai PER oleh kemampuan udang dalam menyerap kandungan protein yang terkandung dalam pakan, semakin tinggi nilai PER dapat menjadi indikator semakin baik pakan yang digunakan sehingga semakin tinggi nilai EPP. Lante et al. (2015), menyatakan bahwa semakin tinggi nilai rasio efisiensi protein memberikan gambaran bahwa kualitas pakan yang diberikan semakin baik, sehingga efisiensi pakannya juga semakin baik. Li et al. (2012) semakin tinggi nilai PER, menandakan bahwa pakan tersebut dapat digunakan secara maksimal. Protein dapat dimanfaatkan secara maksimal untuk pertumbuhan karena ikan mampu memanfaatkan karbohidrat lebih baik untuk metabolisme sehingga protein yang ada lebih dapat dimanfaatkan secara maksimal untuk pertumbuhan.

Penambahan asam amino lisin pada pakan komersil tidak memberikan pengaruh nyata $(P<0,05)$ terhadap $S R$ udang vaname. Hasil penelitian menunjukkan kelulushidupan udang vaname berada di kisaran antara $84,44-88,89 \%$ menunjukkan nilai yang baik. Fuady et al. (2013) menyatakan bahwa tingkat kelulushidupan udang vaname dengan nilai lebih dari $84 \%$ dianggap sudah baik. Widyantoko et al. (2015), menyatakan besar kecilnya kelulushidupan dipengaruhi oleh faktor eksternal yang meliputi kualitas air, padat penebaran dan jumlah penebaran.

\section{KESIMPULAN}

Kesimpulan dari hasil penelitian ini adalah penambahan asam amino lisin pada pakan komersial berpengaruh sangat nyata $(P<0,01)$ terhadap SGR, EPP, FCR dan PER, namun tidak berpengaruh nyata $(P>0,05)$ terhadap SR udang vaname (L. vannamei). Dosis optimal asam amino lisin dalam pakan komersial udang vaname (L. vannamei) untuk SGR sebesar 2,33\%, EPP sebesar 2,39\%, FCR sebesar 2,37\% dan PER sebesar 2,09\% menghasilkan SGR maksimal sebesar 4,72\%/hari, EPP maksimal sebesar $81,35 \%$, FCR maksimal sebesar 1,23, dan PER maksimal sebesar 2,57.

\section{DAFTAR PUSTAKA}

Ahmed, I. \& Khan, M.A., 2004. Dietary lysine requirement of fingerling Indian major carp, Cirrhinus mrigala (Hamilton). Aquacul., 235: 499-511. 
Alam, M. S., Watanabe, W.O., Sullivan, K.B., Rezek, T.C. \& Seaton, P.J. 2012. Replacement of Menhaden Fish Meal Protein by Solvent-Extracted Soybean Meal Protein in the Diet of Juvenile Black Sea Bass Supplemented with or without Squid Meal, Krill Meal, Methionine, and Lysine. North Am. J. Aquacul., 74(2):251265.

Biswas, P., Pal, A.K., Sahu, N.P., Reddy, A.K., Prusty, A.K. \& Misra, S. 2006. Lysine and/or phytase supplementation in the diet of Penaeus monodon (Fabricius) juveniles: Effect on growth, body composition and lipid profile. Aquacul., 265:253-260.

Cao, J.M., Chen, Y., Zhu, X., Huang, Y.H., Zhao, H.X., Li, G.L., Lan, H.B., Chen, B., \& Pan, Q., 2012. A study on dietary L-lysine requirement of juvenile yellow catfish Pelteobagrus fulvidraco. Aquac. Nutr, 18: 35-45.

Deng, D.F., Dominy, W., Yong Ju, Z., Koshio, S., Murashige, R., \& Wilson, R.P. 2010. Dietary lysine requirement of juvenile Pacific threadfin (Polydactylus sexfilis). Aquacul., 308:44-48.

Ebeneezara, S., Vijayagopala, P., Srivastavab, P.P., Guptab, S., Sikendrakumarb, Vargheseb, T., Prabua, D.L., Chandrasekara, S., Varghesea, L., Sayooja,P., Tejpalc, C.S. \& Wilsona, L 2019. Dietary lysine requirement of juvenile Silver pompano, Trachinotus blochii (Lacepede, 1801). Aquacul. 511:734234.

Fuady M.F., Supardjo, M.N., \& Haeruddin. 2013. Pengaruh Pengelolaan Kualitas Air terhadap Tingkat Kelulushidupan dan Laju Pertumbuhan Udang Vaname (Litopenaeus vannamei) di PT. Indokor Bangun Desa, Yogyakarta. J. Maq. Manag. Aqua. Res., 2(4):155-162.

Giri, I.N.A., Sentika, A.S., Suwirya, K. \& Marzuqi, M. 2009. Kandungan Asam Amino Lisin Optimal Dalam Pakan Untuk Pertumbuhan Benih Ikan Kerapu Sunu, Plectropomus Leopardus. J. Ris. Akuakul., 4(3):357-366.

Jin, M., Xiong, J,, Zhou, Q., Yuan, Y., Wang, X. \& Sun, P. 2018. Dietary Yeast Hydrosilate and Brewer Yeast Supplementation Could Enhance Growth Performance, Innate Immunity Capacity and Ammonia Nitrogen Stress Resistance Ability of Pacific White Shrimp (Litopenaeus vannamei). Fish and Shellfish Immnology. 82: 121-129.
Khalida, A., Agustono \& Paramita W.L. 2017. Penambahan Lisin Pada Pakan Komersial Terhadap Retensi Protein Dan Retensi Energi Ikan Bawal Air Tawar (Colossoma Macropomum). J. Ilmiah Perikan. Kel., 9(2):98-106.

Khan, M.A. \& Abidi, S.F., 2011 . Effect of dietary L-lysine levels on growth, feed conversion, lysine retention efficiency and haematological indices of Heteropneustes fossilis(Bloch) fry. Aquac. Nutr. (17):e657-e667.

Lante, S., Usman, \& Laining, A. 2015. Pengaruh Kadar Protein pakan Terhadap Pertumbuhan dan Sintasan Udang Windu, Penaeus monodon Fab. Transfeksi. Universitas Gadjah Mada. J. Perikanan, 1: 10-17

Li, Y., Bordinhon, A.M., Davis, D.A., Zhang, W. \& Zhu, X. 2012. Protein: Energy Ratio in Practical Diets for Nile Tilapia Oreochromis niloticus. Aquacult. Int., 3:1 1.

Mukhtar, B., Malik, M.F., Shah, S.H., Azzam, A., Slahuddin \& Liaqat, I. 2017. Lysine Supplementation in Fish Feed. Int. J. App. Biol. Forens., 1 (2):26-31.

Nguyen, M.V., Ronnestad, I., Buttle, L., Lai, H.V., \& Espe, M., 2013. Imbalanced lysine to arginine ratios reduced performance in juvenile cobia (Rachycentron canadum) fed high plant protein diets. Aquac. Nutr, 20:25-35.

Palavesam, A., Beena, S. \& Immanuel, G.. 2008. Effect of L-Lysine Supplementation with Different Protein Levels in Diets on Growth, Body Composition and Protein Metabolism in Pearl Spot Etroplus Suratensis (Bloch). Turkish J Fish. Aqua. Sci., 8:133-139

Pramana, A., Agustono \& Nurhajati, T. 2017. Penambahan Lisin Pada Pakan Komersial Terhadap Laju Pertumbuhan, Rasio Konversi Pakan Dan Efisiensi Pakan Udang Galah (Macrobrachium Rosenbergii). J. Aquacul. Fish Health, 7(1): 18-24.

Rachmawati,D., Hutabarat, J., Samidjan, I., danWindarto, S. 2019. The effects of papain enzyme-enriched diet on protease enzyme activities, feed efficiency, and growth of fingerlings of Sangkuriang catfish (Clarias gariepinus) reared in tarpaulin pool. AACL Bioflux, 12(6):2177-2187.

Salama, M., Fatma, Abed, H.E. \& Alaa, A. ElDahhar. 2013. Effect of Amino Acids (Lysine and Methionine + Cyctine) 
Supplementation Rate on Growth Performance and Feed Utilization of Sea Bass (Dentrarshus laborax) Larvae. J. Arabian Aquacul. Soc. Arabian Aquacul. Conf., 8(1):37-52.

SNI: 01-8037-2014. udang vaname (Litopenaeus vannamei, Boone 1931) Bagian 1: Produksi Induk Indoor. Badan Standarisasi Nasional. Jakarta.

Steel, R.G.D., Torrie, J.H. \& Dickey, D.A..1996. Principles and Procedures of Statistics: A Biometrical Approach. 3rd Edition, McGraw Hill, Inc. Book Co., New York, pp: 352-358.

Tacon, A.G.J. 1987. Nutrition and Feeding of Farmed Fish and Shrimp, Government Coorperative Progamme (FAO). Brazil.

Wang, A., Ran, C., Wang, Y., Zhang, Z., Ding, Q., Yang, Y., Olsen, R.E., Ringo, E., Bindelle, J. \& Zhou, Z. 2018. Use of Probiotics in Aquaculture of China - a Review of the Past Decade. Fish and Shellfish Immunol., 86:734-755. doi: 10.1016/j.fsi.2018.12.026
Widyantoko, W., Pinandoyo \& Herawati, V.E. 2015. Optimalisasi Penambahan Tepung Rumput Laut Coklat (Sargassum Sp.) Yang Berbeda Dalam Pakan Terhadap Pertumbuhan Dan Kelulushidupan Juvenil Udang Windu (Penaeus Monodon). J. Aquacul. Manag. Technol. 4(2): 9-17.

Xia, Z. dan S. Wu. 2018. Effects of Glutathione on the Survival, Growth Performance and Non-specific Immunity of White Shrimp (Litopenaeus vannamei). Fish and Shellfish Immunol., 73:141-144.

Xie, F., Zeng, W., Zhou, Q., Wang, H., Wang, T., Zheng, C. \& Wang, Y. 2012. Dietary lysine requirement of juvenile Pacific white shrimp, Litopenaeus vannamei. Aquacul. 433: 116-121.

Xu, W.J., Morris, T.C., \& Samocha, T.M. 2018. Effects of Two Commercial Feeds for Semi-Intensive and Hyper-Intensive Culture and Four $\mathrm{C} / \mathrm{N}$ Ratios on Water Quality and Performance of Litopenaeus vannamei Juveniles at High Density in Biofloc-Based, Zero-Exchange Outdoor Tanks. Aquacul. 4(9):194-202. 